\title{
Article \\ Trafficking of Full-Length and N-Terminally Truncated Cathepsin B in Human Colorectal Carcinoma Cells
}

\author{
Tripti Tamhane ${ }^{1, \dagger}{ }^{,}$Robin W. Njenga ${ }^{1}$, Roberta E. Burden ${ }^{2} \oplus$, Heiko Büth ${ }^{1}{ }^{\ddagger}$, Gunhild M. Maelandsmo ${ }^{3}$, \\ Mads H. Haugen ${ }^{3}$, Christopher J. Scott ${ }^{4}$ and Klaudia Brix ${ }^{1, * D}$ \\ 1 Department of Life Sciences and Chemistry, Jacobs University Bremen, Campus Ring 1, \\ D-29759 Bremen, Germany; trta@dtu.dk (T.T.); rnjenga@jacobs-alumni.de (R.W.N.); \\ heiko.bueth@lonza.com (H.B.) \\ 2 School of Pharmacy, Medical Biology Centre, Queen's University Belfast, 97 Lisburn Road, \\ Belfast BT9 7BL, UK; r.burden@qub.ac.uk \\ 3 Department of Tumor Biology, Institute for Cancer Research, Oslo University Hospital-The Norwegian \\ Radium Hospital, 0424 Oslo, Norway; g.m.malandsmo@ous-research.no (G.M.M.); \\ mads.haugen@rr-research.no (M.H.H.) \\ 4 Patrick G. Johnston Centre for Cancer Research, Medical Biology Centre, Queen's University Belfast, 97 \\ Lisburn Road, Belfast BT9 7AE, UK; c.scott@qub.ac.uk \\ * Correspondence: k.brix@jacobs-university.de; Tel.: +49-421-200-3246 \\ † Present address: Department of Health Technology, Section of Experimental and Translational Immunology, \\ Technical University of Denmark, 2800 Kongens Lyngby, Denmark. \\ $\ddagger$ Present address: Lonza Cologne GmbH, Nattermannallee 1, 50829 Köln, Germany.
}

Citation: Tamhane, T.; Njenga, R.W.; Burden, R.E.; Büth, H.; Maelandsmo, G.M.; Haugen, M.H.; Scott, C.J.; Brix, K. Trafficking of Full-Length and N-Terminally Truncated Cathepsin B in Human Colorectal Carcinoma Cells. Appl. Sci. 2021, 11, 11936. https: / / doi.org/10.3390/ app112411936

Academic Editors: Maciej Gagat and Anna Klimaszewska-Wiśniewska

Received: 25 November 2021 Accepted: 12 December 2021 Published: 15 December 2021

Publisher's Note: MDPI stays neutral with regard to jurisdictional claims in published maps and institutional affiliations.

Copyright: (c) 2021 by the authors Licensee MDPI, Basel, Switzerland. This article is an open access article distributed under the terms and conditions of the Creative Commons Attribution (CC BY) license (https:// creativecommons.org/licenses/by/ $4.0 /)$.
Featured Application: Full-length cathepsin B is sorted to endo-lysosomes of colorectal carcinoma cells, while N-terminally truncated cathepsin B accumulates in aggresomes.

Abstract: Cathepsin B is an endo-lysosomal cysteine protease. However, its increased expression and altered localization to the extracellular space, to mitochondria, or to the nucleus has been linked to tumor progression. In the present study, we show enhanced levels of cathepsin B in adenocarcinoma tissue in comparison to adjacent normal colon. Additionally, cathepsin B was observed in the nuclear compartment of mucosal cells in adenocarcinoma tissue samples and in the nuclei of the colorectal carcinoma cell line HCT116. Accordingly, a distinct 40-kDa form of cathepsin B was detected in HCT116 cells, which is proposed to represent a specific form lacking the signal peptide and parts of the propeptide. Trafficking studies with an EGFP-tagged N-terminally truncated form, mimicking the 40-kDa form, demonstrated accumulation in aggresome-like inclusion bodies, while EGFP-tagged full-length cathepsin B revealed regular sorting to endo-lysosomes. We conclude that the identity of nuclear cathepsin B in colorectal adenocarcinoma (in situ) and in carcinoma cells (in vitro) cannot be attributed to either full-length or 40-kDa N-terminally truncated cathepsin B forms. Hence, future studies are needed to demonstrate which form/s of cathepsin B may be sorted to the nuclei of colorectal carcinoma cells, and whether redundant regulation of related cathepsin expression occurs.

Keywords: aggresomes; cathepsin B; colorectal cancer; enhanced green fluorescent protein tagging; nuclear specific protease forms; protein engineering; protein misfolding; protein trafficking

\section{Introduction}

Cysteine cathepsins play an important role in intra- and extra-cellular protein degradation and thus function as key enzymes in various physiological processes, which is specifically true for the ubiquitously expressed endo- and exo-peptidase cathepsin B [1-5]. Cathepsin B belongs to the cysteine peptidases, and is classically regarded as a typical endolysosomal enzyme, although its expression and localization are often altered, particularly in tumor cells. Therefore, it has been linked to tumor cell invasion and metastasis [6-18]. In normal human cells, cathepsin B mRNA encodes a 47-kDa polypeptide chain which 
consists of a prepeptide, the signal peptide, a propeptide, and a mature polypeptide chain that can be processed to yield proteolytically active single- and two-chain forms, depending on the removal of an internal propeptide between the light and heavy chains of cathepsin B. The signal peptide targets the protein for entry into the lumen of the rough endoplasmic reticulum (rER), from where it is transported to the Golgi, eventually reaching its final destination, the endo-lysosomes $[4,19]$. The human cathepsin B gene is comprised of 12 exons, and in tumor cells a number of different mRNA variants may be generated by alternative splicing [20]. A splice variant has been detected that lacks exons 2 and 3, which encodes a protein lacking the 17 amino acid signal peptide and the first 34 amino acids of the propeptide. This N-terminally truncated cathepsin B form is not sorted like the regular preproenzyme via the ER and the Golgi apparatus to endo-lysosome [21-23]. Rather, the N-terminally truncated specific form of cathepsin B was detected in the nucleus and may be imported into the mitochondrial matrix. Such different and unusual sub-cellular locations of cysteine cathepsins have been reported in various types of cancer tissue such as breast carcinoma, colon carcinoma, thyroid carcinoma, and melanoma [5,8,9,21,24-27]. Furthermore, over-expression of N-terminally truncated cathepsin B that is destined to mitochondria can result in the initiation of cell death pathways $[25,28]$. N-terminally truncated forms have also been reported for other cathepsins, such as cathepsin $\mathrm{H}$ in human prostate cancer cells [29], cathepsin L in embryonic fibroblasts [30], or breast carcinoma cells [31], and in cathepsin L2/V in thyroid epithelial cells [32]. Thus, according to present information available, most of the $\mathrm{N}$-terminally truncated forms of cysteine cathepsins are associated with pathological conditions, more evidently with cancer $[8,12,16-18,32-34]$.

In the present study, we investigated the localization of cathepsin B in adenocarcinoma tissue in comparison to adjacent normal colon, demonstrating altered subcellular localization. Hence, further investigations were carried out on the trafficking pathway of full-length human cathepsin B in comparison to that of an $\mathrm{N}$-terminally truncated form of the same protease in the colorectal (CRC) adenocarcinoma-derived in vitro cellular model HCT116. Additionally, we studied the possible effect of cathepsin B on cell cycle progression of HCT116 cells, because we had recently observed that a related enzyme, cathepsin L, promotes G1-S phase transition in CRC cells [35]. The results indicate that the 40-kDa of cathepsin B detected in HCT116 cells is likely to be sorted to peri-nuclear aggresomes. In addition, the data suggest that mis-sorting of cathepsin B forms to the nucleus of CRC cells has no obvious proteolytic function on cell cycle progression.

\section{Materials and Methods}

\subsection{Cell Culture and Tissue Microarrays}

Intestine epithelial (IEC6) and the human colorectal carcinoma (CRC) cell line HCT116 were obtained from ECACC (Salisbury, UK) or ATCC (Teddington, Middlesex, UK), respectively, and cultured at $37^{\circ} \mathrm{C}$ and $5 \% \mathrm{CO}_{2}$ in Dulbecco's Modified Eagle's Medium with $4 \mathrm{mM}$ L-glutamine (Lonza, Verviers, Belgium) and $0.1 \mathrm{U} / \mathrm{mL}$ bovine insulin (SigmaAldrich, Taufkirchen, Germany), or in RPMI-1640 (Biowhittaker ${ }^{\mathrm{TM}}$, Verviers, Belgium) supplemented with $10 \%$ fetal calf serum (Lonza, Cologne, Germany), respectively, as previously described [35].

Purchased tissue microarrays (TMAs; Biomax, Rockville, MD, USA) consisted of sections from cancer-adjacent normal colon and adenocarcinoma human tissue. Prior to immunolabeling (see below), the sections were deparaffinated as previously described [35].

\subsection{Plasmid Construction and Transfection}

The cDNA of full-length human cathepsin B was obtained from HaCaT cells, a human keratinocyte cell line, and cloned into the mammalian expression vector $p$ EGFP-N1 (Clontech, Heidelberg, Germany) using the same strategy as before [19] with EcoRI and BamHI as restriction enzymes, which resulted in the construction of the plasmid phCB-EGFP [36]. The EGFP-tagged full-length cathepsin B chimeric protein consists of the signal peptide, the propeptide, the mature form of cathepsin B and EGFP (see below). 
To construct EGFP-tagged N-terminally truncated human cathepsin $B$, the vector ph52NCB-EGFP was engineered with cDNA of cathepsin B derived from the human colorectal carcinoma cell line HCT116. To obtain N-terminally truncated human cathepsin $B$, the cathepsin B sequence was initiated from the alternative start site; i.e., methionine at amino acid position 52 and cloned into the vector $p$ EGFPN1 using XhoI and BamHI restriction sites. Thus, the vector encodes for a chimeric protein lacking the 17 amino acid signal peptide and the first 34 amino acids of the propeptide region of cathepsin B (see below).

For expression, sub-confluent cell cultures of HCT116 cells were transfected with $p$ hCB-EGFP and $p$ h52NCB-EGFP, using the transfection reagent $X$-treme GENE HP DNA according to the supplier's instructions (Roche Diagnostics, Mannheim, Germany).

\subsection{Cell Cycle Synchronization}

HCT116 cells were arrested in the G1/G0, early S, and G2/M phases by serumstarvation, double thymidine block, and nocodazole treatment, respectively, as previously described [35]. Transfection was for $24 \mathrm{~h}$ before cell cycle arrest. During chase periods, cells were treated with $10 \mu \mathrm{M}$ CA074 (Merck Biosciences GmbH, Darmstadt, Germany), a cathepsin B specific inhibitor.

\subsection{Immunofluorescence Labeling}

Colon TMA slides were subjected to immunofluorescence staining as previously described [35], using goat anti-mouse cathepsin B (1:100; Neuromics through Acris Antibodies, Herford, Germany; GT15047), Alexa 488- or Alexa 546-coupled secondary antibodies (1:200; Molecular Probes, Karlsruhe, Germany), and $5 \mu \mathrm{M}$ Draq5 $5^{\mathrm{TM}}$ (Biostatus Limited, Shepshed Leicestershire, UK) for counter-staining of nuclear DNA.

Immunofluorescence labeling of different sub-cellular compartments of transfected or non-transfected cells was performed using rabbit anti-human protein disulfide isomerase (PDI) (1:100; Stressgen through Enzo Life Sciences GmbH, Lörrach, Germany, SPA-890), mouse anti-human Golgin 97 (1:100; Molecular Probes, Karlsruhe, Germany, A-21270), or mouse anti-human Lamp2 (lysosomal-associated membrane protein 2) (1:10; Developmental Studies Hybridoma Bank, University of Iowa, Iowa City, IO, USA, H4B4) primary antibodies and the respective Alexa 488- and Alexa 546-coupled secondary antibodies, along with Draq5 ${ }^{\mathrm{TM}}$ as mentioned above, while specific primary antibodies were omitted in negative controls.

\subsection{Aggresome Detection}

Cells were transfected with $p$ EGFP, $p$ hCB-EGFP, and $p$ h52NCB-EGFP as described above. Aggresome detection was performed with the ProteoStat ${ }^{\circledR}$ Aggresome Detection kit according to the manufacturer's instructions (Enzo Life Sciences GmbH, Lörrach, Germany). For controls, cells were incubated in the $5 \mu \mathrm{M}$ cell-permeable proteasome inhibitor MG-132 to induce accumulation of misfolded protein under normal tissue culture conditions. After washing with PBS, cells were fixed in $4 \%$ paraformaldehyde for $15 \mathrm{~min}$ at room temperature and permeabilized in 0.5\% Triton X-100, 3 mM EDTA, $\mathrm{pH} 8.0$, in assay buffer on ice for 30 min. After a brief washing step with PBS, cells were stained using the ProteoStat ${ }^{\circledR}$ Aggresome Detection Reagent for $30 \mathrm{~min}$ at room temperature in the dark. Finally, washed cells were mounted in an embedding medium.

\subsection{Microscopy}

Sample inspection was with a Zeiss LSM 510 META confocal laser scanning microscope (Carl Zeiss GmbH, Jena, Germany). Images were analyzed with the LSM 510 software, release 3.2 (Carl Zeiss). Detector gain and pinhole settings were kept constant to quantify cysteine cathepsin levels in colon, for which three images each were taken from sections of normal $(n=6)$ and adenocarcinoma samples $(n=12)$. Intensities of nuclear localized cathepsin signals were determined from at least five images per preparation. 
CellProfiler ${ }^{\mathrm{TM}}$ software was used to set up pipelines quantifying signal intensities over nuclear areas, i.e., by masking with the corresponding Draq5 ${ }^{\mathrm{TM}}$-positive area $[37,38]$.

\subsection{Subcellular Fractionation, SDS-PAGE, and Immunoblotting}

Subcellular fractions were prepared as previously described [35,39]. Fraction proteins were separated on $12.5 \%$ or $8-18 \%$ gradient SDS-polyacrylamide gels (GE Healthcare through Sigma-Aldrich, 80-1255-53). The PageRuler Prestained Protein Ladder (Fermentas through Thermo Scientific, Schwerte, Germany) was used as a molecular mass marker. Proteins were transferred onto a nitrocellulose membrane by semi-dry blotting. After blocking, the blots were incubated with goat anti-mouse cathepsin B (1:1000; Neuromics, Hiddenhausen, Germany, GT15047) and HRP-coupled secondary antibodies as previously described [40].

\subsection{FACS Analysis}

FACS analysis was performed as previously described [35]. Briefly, after the desired treatment and synchronization of HCT116 cultures, 70\% ethanol was used for fixation and $10 \mu \mathrm{g} / \mathrm{mL}$ propidium iodide was used for counter-staining of cellular DNA content. Analysis was performed with FACS Calibur (BD GmbH, Heidelberg, Germany), using FlowJo software (Tree Star, Ashland, OR, USA). Total cell counts were set to $100 \%$ and proportions of cells in $\mathrm{G} 1 / \mathrm{G} 0, \mathrm{~S}$, and G2/M were calculated as percentages.

\subsection{Densitometry Analysis and Statistical Evaluations}

TINA software (Raytest, Straubenhardt, Germany) was used for densitometry. All experiments were repeated at least three times with a minimum of triplicates. Evaluation of statistical significance was carried out by two-tailed, unpaired Student's $t$-test using GraphPad Prism 5.04 (GraphPad, San Diego, CA, USA).

\section{Results}

3.1. Elevated Levels and Dispersed Sub-Cellular Distribution of Cathepsin B in Adenocarcinoma of Colon Tissue

In the present study, we investigated the expression levels and localization of cysteine cathepsin B in tissue microarrays (TMA) to compare adenocarcinoma tissue with adjacent, normal colon tissue. Cathepsin B-specific immunofluorescence signals were detected within vesicles of epithelial cells of normal colon tissue (Figure 1A, arrowheads). Distribution patterns were altered in adenocarcinoma cells, in that cathepsin B-positive vesicles were more dispersed throughout the cytoplasm and often located at the apical plasma membrane in adenocarcinoma tissue (Figure 1B, open arrowheads). Additionally, a prominent signal for cathepsin $B$ within the nuclei of several adenocarcinoma cells was observed (Figure $1 \mathrm{~B}^{\prime}$, arrow). Quantitative determination of fluorescence intensities revealed significantly elevated levels of the cathepsin B in adenocarcinoma tissue compared with normal, adjacent tissue (Figure 1C).

\subsection{Nuclear Localization of Cathepsin B in the HCT116 Human Colorectal Carcinoma Cell Line}

Immunofluorescence and immunoblotting experiments were also performed on the IEC6 and HCT116 in vitro cellular models for normal intestine epithelial and colorectal carcinoma cells, respectively. Labeling of cathepsin B revealed the expected localization in vesicles accumulating in the peri-nuclear region characteristic for endo-lysosomal distribution patterns in IEC6 cells (Figure 2A, arrowheads). HCT116 cells recapitulated the phenotype of adenocarcinoma cells in situ, i.e., cathepsin B was present in reticular and vesicular structures throughout the cytoplasm in addition to a main localization in the peri-nuclear region (Figure 2B, arrowheads), while cathepsin B-specific staining was also detected in the nuclei of this CRC cell line (Figure 2B, arrows). Quantitative analysis using the semi-automated image analysis tool CellProfiler ${ }^{\mathrm{TM}}$ revealed significantly higher levels 
of nuclear cathepsin B-specific immunopositive signals in HCT116 cells in comparison to normal IECs (Figure 2C).
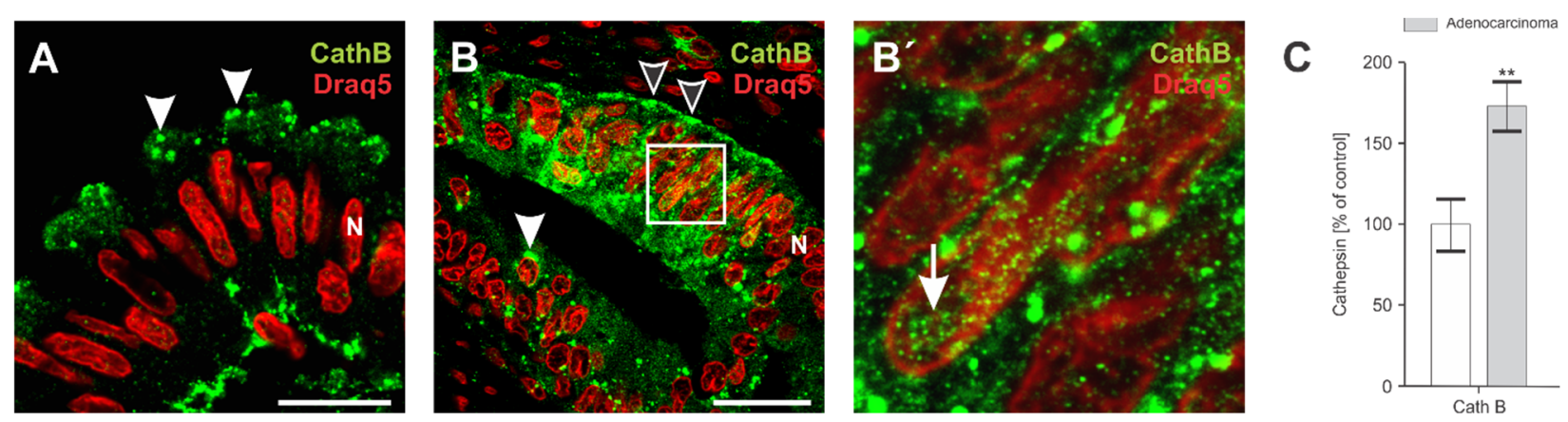

Figure 1. Cathepsin B is up-regulated and dispersed in adenocarcinoma of colon tissue. (A,B') Immunohistochemistry of normal human colon (A) adjacent to adenocarcinoma tissue (B) after immunostaining of cathepsins B (green signals). The boxed area in $(\mathbf{B})$ is magnified in $\left(\mathbf{B}^{\prime}\right)$. Cathepsin B was observed in vesicles (arrowheads), associated with the apical plasma membrane domains (open arrowheads), and in nuclei of mucosa cells (arrow). Nuclei were counter-stained with Draq5 $5^{\mathrm{TM}}$ (red signals). Scale bars represent $50 \mu \mathrm{m}$. (C) Quantitation of immunofluorescence intensities is depicted as a bar chart with cathepsin B in adenocarcinoma (grey bar) and normal colon tissue (open bar). Values are given as means \pm standard deviations. Levels of significance are indicated as ${ }^{* *}$ for $p<0.01$.
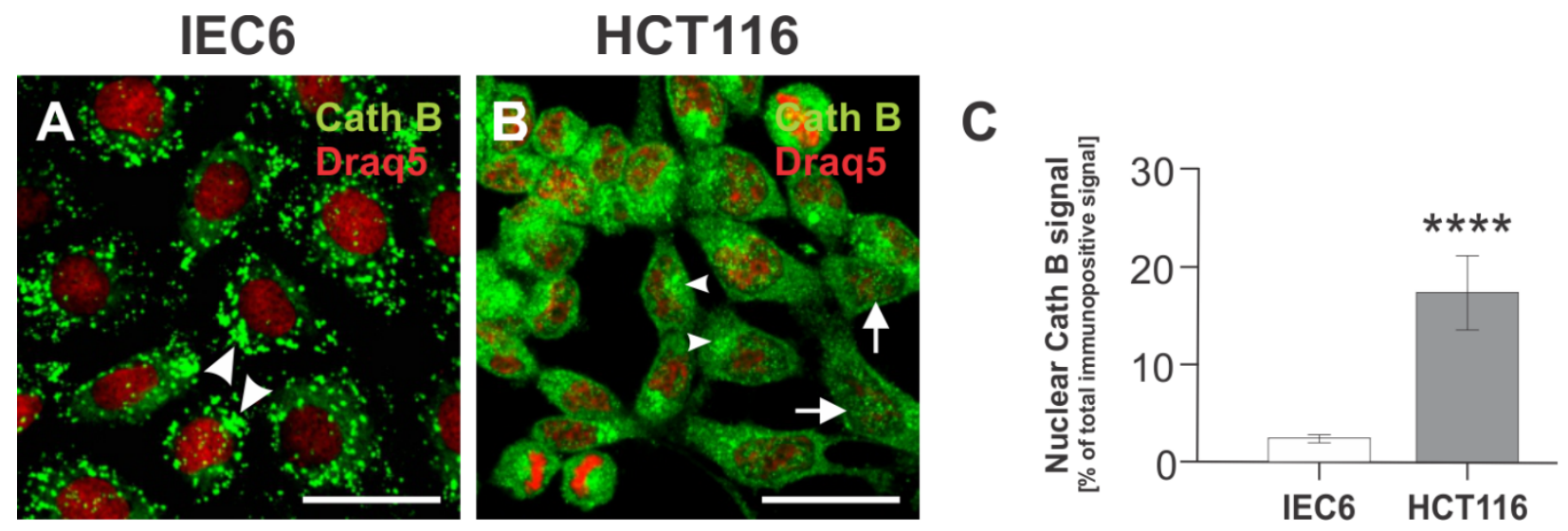

Figure 2. Cathepsin B localization in intestine epithelial and CRC cells. (A,B) Confocal laser scanning micrographs of IEC6 (A) and HCT116 cells (B) stained with cathepsin B-specific antibodies (green signals). Arrowheads point to cathepsin B-positive vesicles accumulating in the perinuclear region; arrows point to immuno-positive signals in nuclei. Nuclei were counter-stained with Draq5 $5^{\mathrm{TM}}$ (red signals). Scale bars represent $20 \mu \mathrm{m}$. (C) Anti-cathepsin B positive signals over nuclear profiles of CRC cells (grey bars) in comparison to normal IEC6 cells (open bar) are depicted in a bar chart. Values are given as means \pm standard deviations. Levels of significance are indicated as ${ }^{* * *}$ for $p<0.0001$.

\subsection{Expression of a 40-kDa Variant of Cathepsin B in CRC Cells}

The expression pattern of molecular forms of cathepsin B was determined using immunoblot and densitometry analysis of anti-cathepsin B-immunopositive signals in whole cell lysates of IEC6 and HCT116 cells. The results showed that cathepsin B was present as the mature single and heavy chain of the two-chain forms in the IEC6 and HCT116 cells (Figure 3A, SC and HC, respectively), while also featuring procathepsin $\mathrm{B}$ in amounts equal to or exceeding those of the mature cathepsin B forms (Figure 3, pro). Importantly, a band at approximately $40 \mathrm{kDa}$ was detected by anti-cathepsin $\mathrm{B}$ immunoblotting in HCT116 cells (Figure 3A, arrow), but not in IEC6 cells. Determination of the relative amounts of the molecular forms of cathepsin $B$ by densitometry showed that the proform of cathepsin B was more prominent than the other molecular forms (Figure 3B, HCT116, pro cf. SC and HC), while the 40-kDa specific form of cathepsin B made up 
as much as approximately $15 \%$ of total cathepsin B present in HCT116 cells (Figure 3B, HCT116, arrow). These findings are in line with those depicted in Figure 2, and the data were supported by our previous observations, detecting a cathepsin B variant of similar molecular mass in nuclear fractions of thyroid carcinoma cells [9].

A
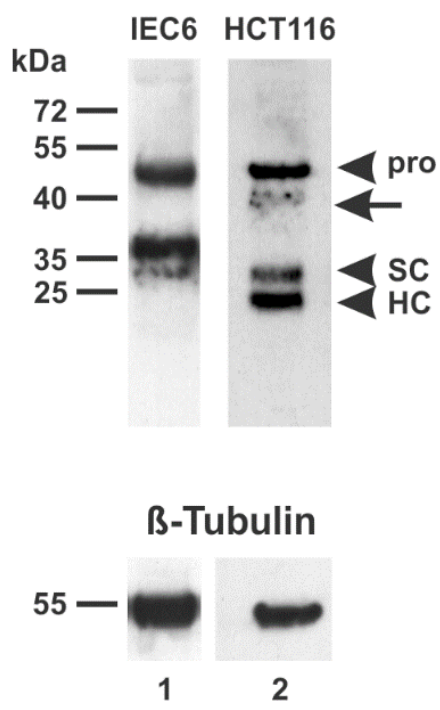

B

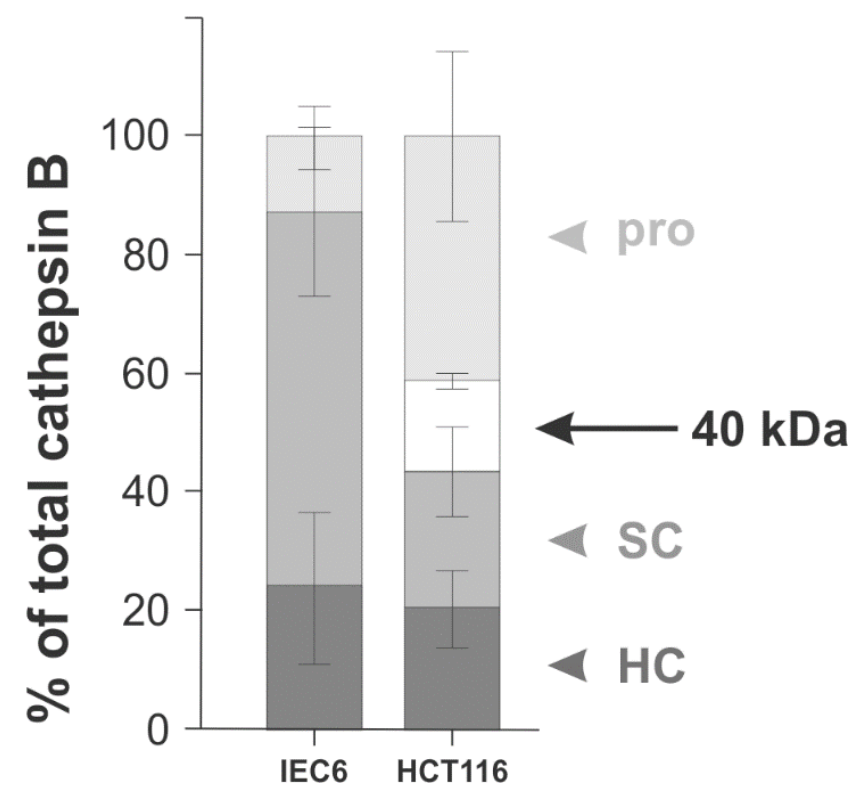

Figure 3. Molecular forms of cathepsin B in intestine epithelial and CRC cells. (A) Immunoblot analyses were performed with whole cell lysates of normal IEC6 and the CRC cell line HCT116 as indicated after staining with cathepsin B-specific antibodies (upper panels). As a loading control, $\beta$-tubulin was used, respectively (lower panels). Molecular mass markers are indicated in the left margins. Note that both cell lines feature pro- (pro), single-chain (SC), and the heavy chain (HC) of two-chain cathepsin B (HC), as expected. HCT116 cells showed an additional band at approximately $40 \mathrm{kDa}$ (arrow). Representative blots are shown, $n=3$. (B) Densitometry was used to determine the relative amounts of distinct cathepsin $B$ forms as a proportion of total cathepsin B. The data revealed an abundance of single-chain of two-chain cathepsin B in IEC6 cells, while the 40-kDa specific form of cathepsin B made up as much as approximately $15 \%$ of total cathepsin B in HCT116 cells.

\subsection{Trafficking of N-Terminally Truncated Human Cathepsin B-EGFP in HCT116 Cells}

As the 40-kDa cathepsin B form made up a prominent proportion of total cathepsin B detected in HCT116 cells, and because nuclear cathepsin B forms are prevalent by immunofluorescence, both in vitro and in situ, we decided to investigate the underlying transport pathways in more detail. Hence, to study the trafficking of $\mathrm{N}$-terminally truncated human cathepsin B tagged with EGFP, thereby mimicking the observed 40-kDa form, HCT116 cells were transiently transfected with $p$ h52NCB-EGFP for $24 \mathrm{~h}$ and compared to cells expressing EGFP-tagged full-length cathepsin B (Figure 4). 

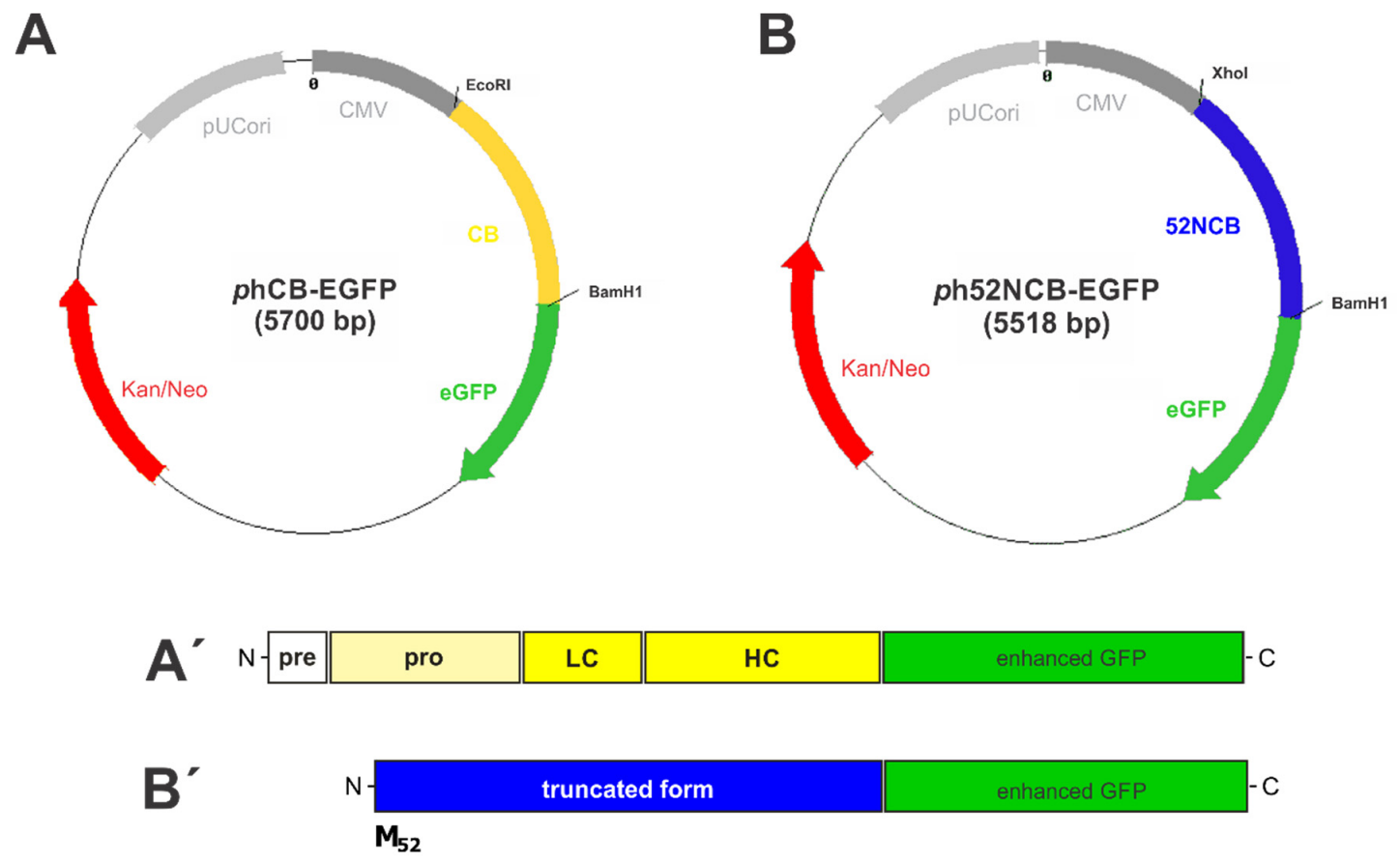

C

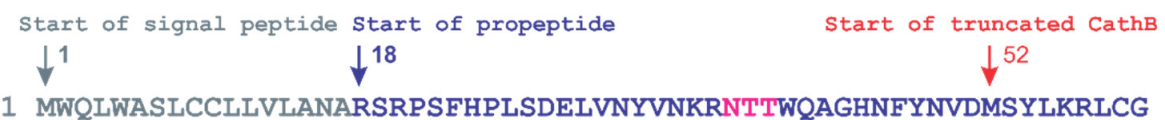

Start of mature enzyme

$\downarrow^{80}$

61 TFLGGPKPPQRVMFTEDLKLPASFDAREQWPQCPTIKEIRDQGSCGSCWAFGAVEAISDR 120

$126 \downarrow \downarrow^{128}$

121 ICIHTNAHVSVEVSAEDLLTCCGSMCGDGCNGGYPAEAWNFWTRKGLVSGGLYESHVGCR 180

181 PYSIPPCEHHVNGSRPPCTGEGDTPKCSKICEPGYSPTYQDKHYGYNSYSVSNSEKDIMA 240

241 EIYKNGPVEGAFSVYSDFLLYKSGYYQHVTGEMMGGHAIRILGWGVENGTPYWLVANSWN 300

301 TDWGDNGFFKILRGQDHCGIESEVVAGIPRTDQYWEKI 339

Figure 4. Schematic depiction and amino acid sequence of phCB-EGFP and ph52NCB-EGFP. Vector maps and schematic representation of the mammalian expression vector phCB-EGFP encoding EGFP-tagged full length cathepsin $B\left(\mathbf{A}, \mathbf{A}^{\prime}\right)$ and ph52NCB-EGFP, which codes for a chimeric protein consisting of N-terminally truncated cathepsin B, which lacks the signal peptide and parts of the propeptide, and is C-terminally fused to EGFP (B, $\left.\mathbf{B}^{\prime}\right)$. The 6 amino acids at the C-terminus of cathepsin $\mathrm{B}$ were replaced by a linker peptide in both constructs to ensure covalent linkage of the EGFP tag. The amino acid sequence of cathepsin B (C) comprises 339 amino acids, where the first 17 amino acids constitute the signal peptide (pre, 1-17), and the sequential 62 amino acids make up the propeptide (pro, 18-79). The mature form of the enzyme consists of 254 amino acid residues (SC, 80-333) with a 6-amino-acid C-terminal extension (333-339). The full-length cathepsin B sequence has two potential N-glycosylation sites at positions Asn 38 and Asn 192 (pink). The mature form of cathepsin B can be found as a single chain or as a two-chain form, i.e., a heavy chain and a light chain that are generated by cleavage between amino acid residues 126 and 129 and are held together by disulfide bonds. Amino acids are given in the single-letter code; pre, signal peptide; pro, propeptide; LC, light chain; HC, heavy chain. 
Co-localization experiments were performed with compartment-specific markers. Antibodies against the ER-resident protein disulfide isomerase (PDI) were used as the ER marker, while the Golgi apparatus was immunolabeled with anti-Golgin 97 antibodies, which visualized a cytosolic protein peripherally associated with Golgi membranes. Antibodies against the lysosomal-associated membrane protein 2 (Lamp2) were used for the staining of endo-lysosomal compartments. Indirect immunofluorescence studies revealed co-localization of the cathepsin B-EGFP chimeric protein with cathepsin B-specific immunostaining indicating co-localization and, thus, co-trafficking of endogenous cathepsin B with expressed CB-EGFP (Figure 5A), thereby proving proper folding and authentic distribution of full-length CB-EGFP. Co-localization of CB-EGFP was also observed with antibodies against the ER-resident protein PDI (Figure 5B). Pronounced co-localization was further observed for the chimeric protein with patchy Golgin 97 staining in close proximity to the nucleus (Figure 5C), while co-localization of the chimeras with Lamp2containing vesicles of the endocytic pathway was observed as well (Figure 5D). These results demonstrated the expected trafficking route followed by CB-EGFP in HCT116 cells, i.e., its biosynthesis at the rER followed by transport to the Golgi apparatus and targeting to the final destination of cathepsin B in endo-lysosomes. The results also provided evidence for intact trafficking pathways taken by hydrolytic enzymes to the endocytic compartments of CRC cells, and highlighted that EGFP-tagging itself did not affect sorting, folding, and trafficking of cathepsin B in HCT116 cells.
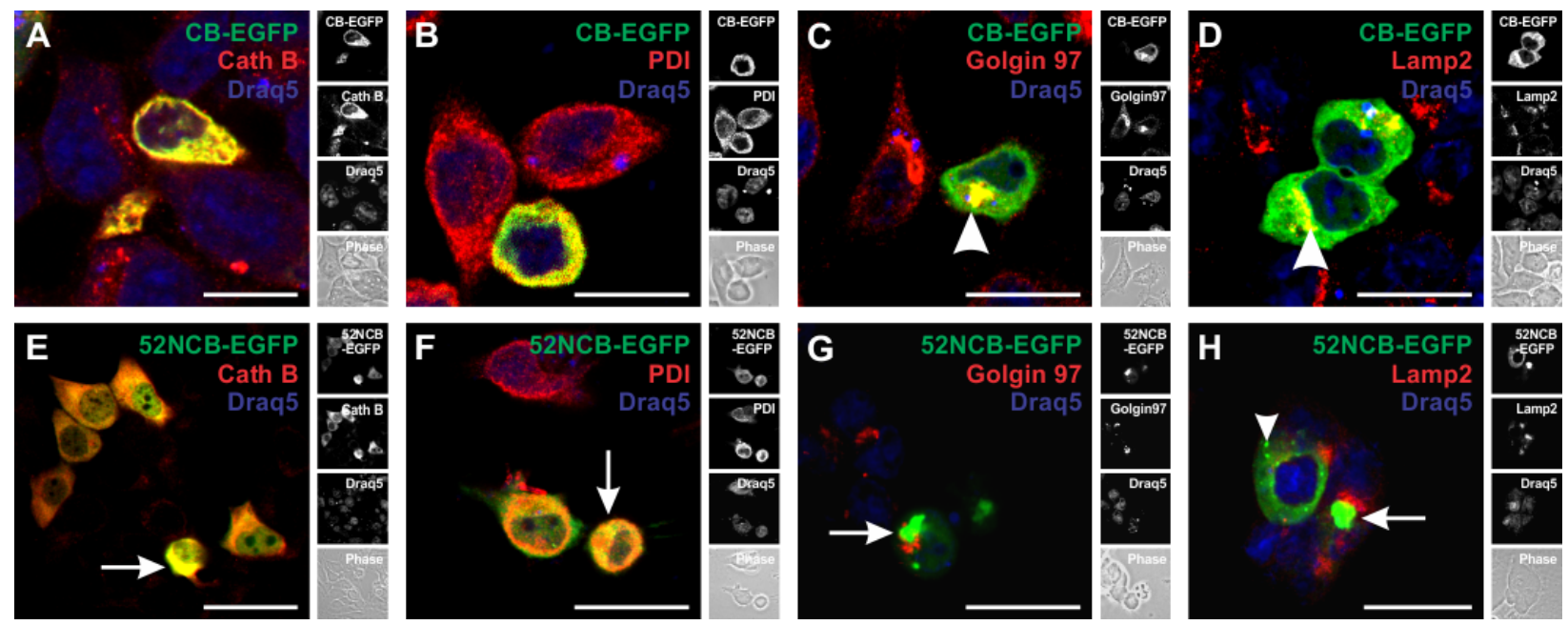

Figure 5. Trafficking of full-length and N-terminally truncated human cathepsin B in HCT116 cells. Micrographs of HCT116 cells after transfection with phCB-EGFP (A-D) and ph52NCB-EGFP (E-H). Merged (A-H) single channel fluorescence (right panels, top and middle) and corresponding phase contrast micrographs (right panels, bottom) were taken with a confocal laser scanning microscope. Immunolabeling with anti-cathepsin B antibodies revealed co-localization with the expressed full-length chimeric protein (A, yellow signal) but not the N-terminally truncated cathepsin B form (E). To detect the sub-cellular localization of the expressed chimeric proteins in detail, compartment-specific antibodies were used, such as PDI for the ER (B,F), Golgin 97 for the Golgi apparatus $(\mathbf{C}, \mathbf{G})$ and Lamp2 for endo-lysosomes $(\mathbf{D}, \mathbf{H})$. Note that chimeric full-length cathepsin B followed the expected trafficking pathway, indicated by yellow signals derived from co-localization with compartment-specific markers. In contrast, the N-terminally truncated cathepsin B showed prominent accumulation in structures adjacent to the nuclei of HCT116 cells (E, arrow), and did not show co-localization with any compartment-specific marker for the secretory and endocytic pathways (F,G,H, absence of yellow signals). Nuclei were counter-stained with Draq5. Scale bars represent $20 \mu \mathrm{m}$.

Expression of the 52NCB-EGFP chimeras in HCT116 cells resulted in the formation of profound juxtanuclear localized structures of considerable size (Figure 5E, arrow) in addition to cytosolic distribution. Occasionally, green signals were observed in the nuclei of HCT116 cells, possibly indicative of the nuclear localization of 52NCB-EGFP. However, the nuclear compartments of HCT116 cells expressing 52NCB-EGFP did not show any 
yellow signal for co-localization with the red signals indicative of anti-cathepsin B-stained structures (Figure 5E), thereby most probably indicating cytosolic cleavage of the chimeric protein and sorting of EGFP to the nuclei of HCT116 cells. No co-localization was detected for 52NCB-EGFP with any of the compartment-specific markers (Figure 5F-H, arrows). 52NCB-EGFP was typically confined to irregularly shaped focal structures in the juxtanuclear region of HCT116 cells (Figure 5E-H, arrows); however, these did not co-localize with the endo-lysosomal marker protein Lamp2.

The results suggested that $\mathrm{N}$-terminally truncated human cathepsin B is possibly synthesized at ribosomes in the cytoplasm and trafficked differently than full-length cathepsin B in HCT116 cells. In this cell line, 52NCB-EGFP accumulated in juxtanuclear foci that resembled aggresomes. These cytoplasmic structures, in which mis-folded proteins are stored away, are typically found in juxtanuclear position close to the microtubuleorganizing center (MTOC) [41].

3.5. N-Terminally Truncated Human Cathepsin B-EGFP Chimeras Accumulate in Aggresome-like Inclusion Bodies of HCT116 Cells

The juxtanuclear aggregates of 52NCB-EGFP in HCT116 cells were further investigated using the ProteoStat ${ }^{\circledR}$ Aggresome detection kit, which detects protein aggregates via a molecular rotor dye that becomes red fluorescent upon binding to aggregated protein due to their structural features [42]. In agreement with our proposal, the green fluorescence of $\mathrm{N}$-terminally truncated human cathepsin B-EGFP chimeras was detected in co-localization with the red signals of the aggresome marker (Figure $6 \mathrm{~A}, \mathrm{~A}^{\prime}$ ), demonstrating that the Nterminally truncated form of human cathepsin B-EGFP accumulated in aggresome-like inclusion bodies of HCT116 cells. To further confirm the rotor dye-positive structures as aggresomes, HCT116 cells were treated with the proteasome inhibitor MG-132 to induce accumulation of mis-folded proteins that can no longer be removed by the proteasomal protein degradation pathway, thus resulting in formation of aggresomes (Figure 6B). It is important to note that no aggresomes were formed in HCT116 cells that transiently expressed full-length human cathepsin B-EGFP or the EGFP tag alone (Figure 6C,D). Therefore, over-expression of 52NCB-EGFP caused its mis-folding; hence, this approach was not considered suitable for the study of the effects of this specific cathepsin B form on cell cycle progression of HCT116 cells.

\subsection{Cathepsin B of HCT116 Cells during Cell Cycle Progression}

Further studies were performed to analyze the possible effects of cathepsin B forms on cell cycle progression of HCT116 cells in analogy with our previous investigations of the role of the related cysteine cathepsins L in this cell line [35]. Localization of cathepsin B was studied in HCT116 cells in different phases of the cell cycle. In particular, HCT116 cell cultures were synchronized and arrested in the G1/G0, S, and G2/M phases of the cell cycle by serum starvation for $24 \mathrm{~h}$, a double thymidine block, and incubation with nocodazole, respectively. This protocol for preparation and the purity of sub-cellular fractions of synchronized and cell cycle-arrested HCT116 cells was previously proven [32,35].

Immunofluorescence labeling with anti-cathepsin B antibodies showed vesicles confined to the peri-nuclear region of HCT116 cells arrested in the G1/G0 phase (Figure 7A). HCT116 cells arrested in the $S$ phase also exhibited cathepsin B prominently in vesicles which were more abundant than in the G1/G0 phase (Figure 7C, cf. Figure 7A). During the G2/M phase, however, cathepsin B-positive vesicles were dispersed throughout the cytoplasm, and cathepsin B staining was also detected in association with condensed chromosomes (Figure 7E, yellow signals). 


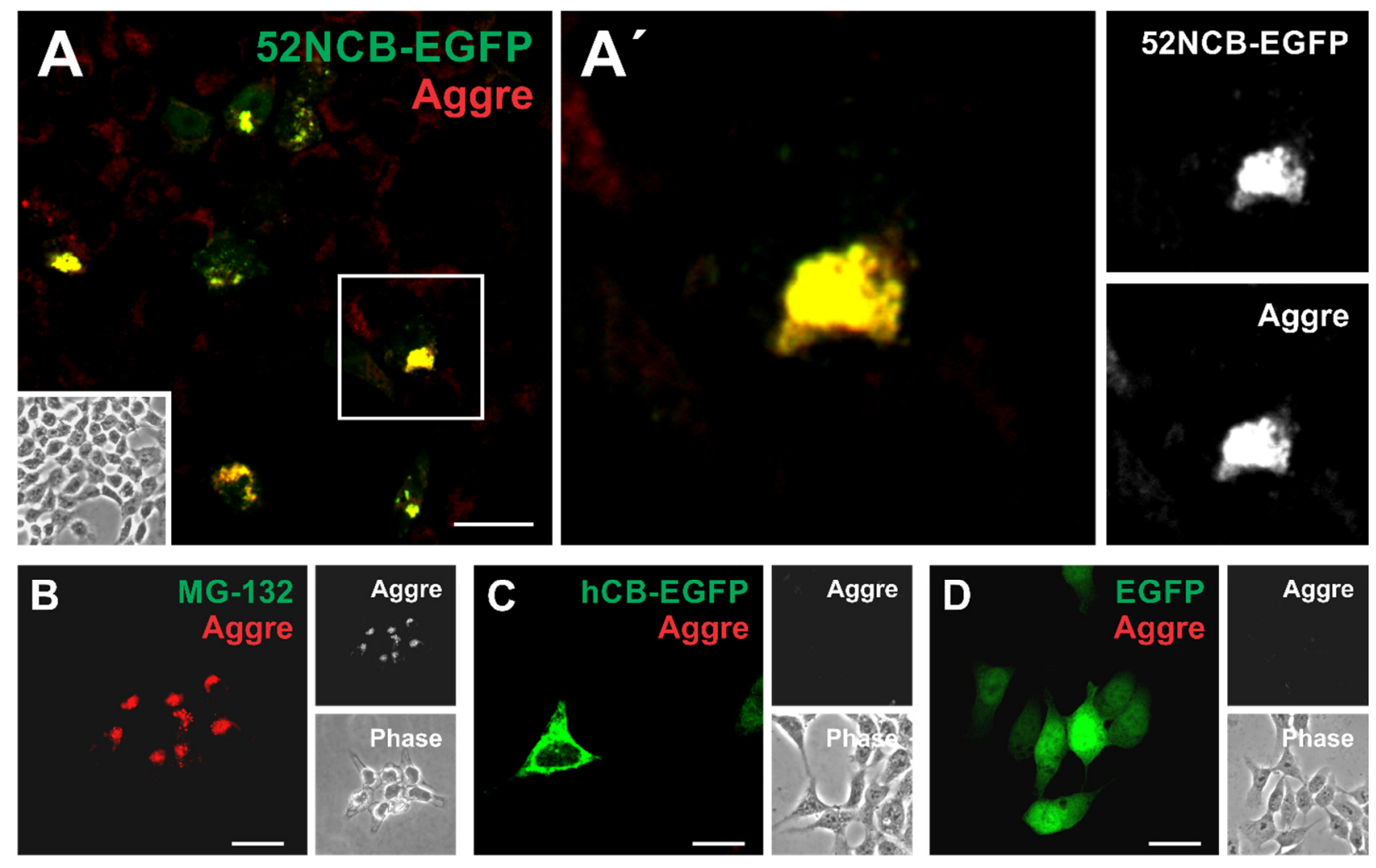

Figure 6. N-terminally truncated human cathepsin B forms are present in aggresomes of HCT116 cells. Aggresome formation in HCT116 cells inspected at $24 \mathrm{~h}$ post-transfection with ph52NCB-EGFP, as detected by using the ProteoStat ${ }^{\circledR}$ aggresome detection dye. Confocal laser scanning micrographs demonstrating merged $\left(\mathbf{A}-\mathbf{D}, \mathbf{A}^{\prime}\right)$ single channel fluorescence and corresponding phase contrast micrographs in the side panels as indicated; the boxed area in image (A) is magnified in $\left(\mathbf{A}^{\prime}\right)$. The N-terminally truncated human cathepsin B accumulated in the juxtranuclear region (green signals), and yellow signal indicated its co-localization with the red signals derived from stained aggresomes $\left(\mathbf{A}, \mathbf{A}^{\prime}\right)$. Aggresome formation was similar in cells expressing 52NCB-EGFP $\left(\mathbf{A}, \mathbf{A}^{\prime}\right)$ and those pretreated with $5 \mu \mathrm{M}$ of the proteasome inhibitor MG-132 (B). Note that cells transfected with full-length, EGFP-tagged human cathepsin B (C) and expressing EGFP alone (D) did not reveal any aggresome formation. Scale bars represent $20 \mu \mathrm{m}$.

Immunoblotting of whole cell lysates $(\mathrm{W})$, lysosomal $(\mathrm{Ly})$ and nuclear fractions $(\mathrm{Nu})$ of HCT116 cells upon arrest in different cell cycle stages, respectively, was performed to study the expression of the different molecular forms of cathepsin B (Figure 7B,D,F, respectively). During the G1/G0 phase, cathepsin B was predominantly present as inactive proform (Figure 7B, pro), while the mature forms of cathepsin $\mathrm{B}$ were mainly detected in the nuclear fractions (Figure 7B, Nu, SC, and HC). Fully processed forms of cathepsin $B$, i.e., mature single- and two-chain forms, were present in all fractions prepared from HCT116 cells arrested in the S-phase, and peaked in the lysosomal fraction (Figure 7D, Ly). Interestingly, the 40-kDa specific form of cathepsin B was observed in both the nuclear and lysosomal fractions of $S$ phase-arrested HCT116 cells (Figure 7D, arrowhead). In cells arrested in the G2/M phase, a band representing procathepsin B was most prominent in the nuclear fraction of HCT 116 cells (Figure 7F, Nu), while mature cathepsin B was detectable only in the lysosomal fraction (Figure 7F, Ly).

The activity analysis of cathepsin B in these sub-cellular fractions showed highest lysosomal activities during the $\mathrm{S}$ phase (Figure $7 \mathrm{H})$, whereas nuclear cathepsin $\mathrm{B}$ activities reached a maximum in the G1/G0 phase, i.e., before cells entered the $S$ phase. The results indicated a possible involvement of cysteine cathepsin B activity in facilitating $\mathrm{S}$ phase entry of HCT116 cells, which was approached subsequently. 


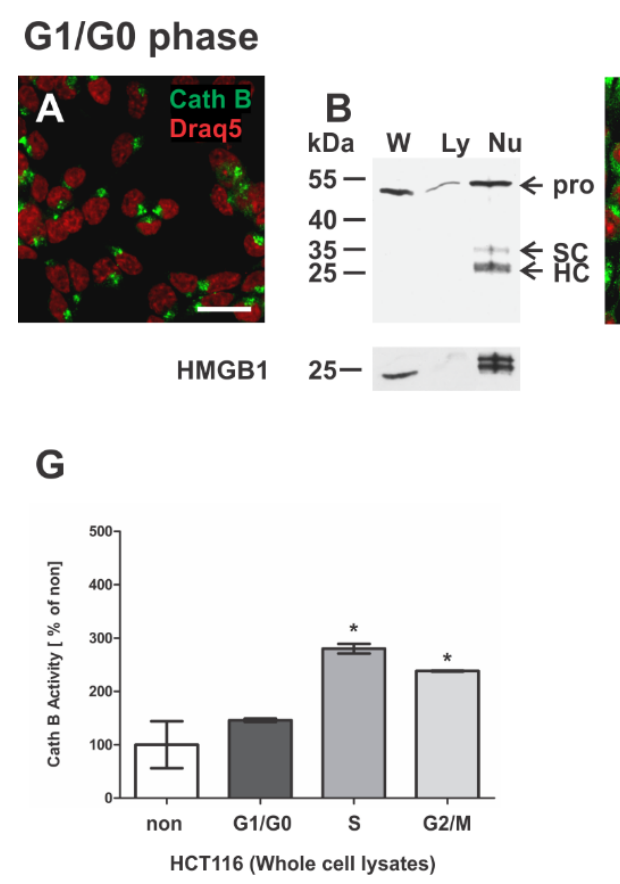

\section{S phase}

G2/M phase
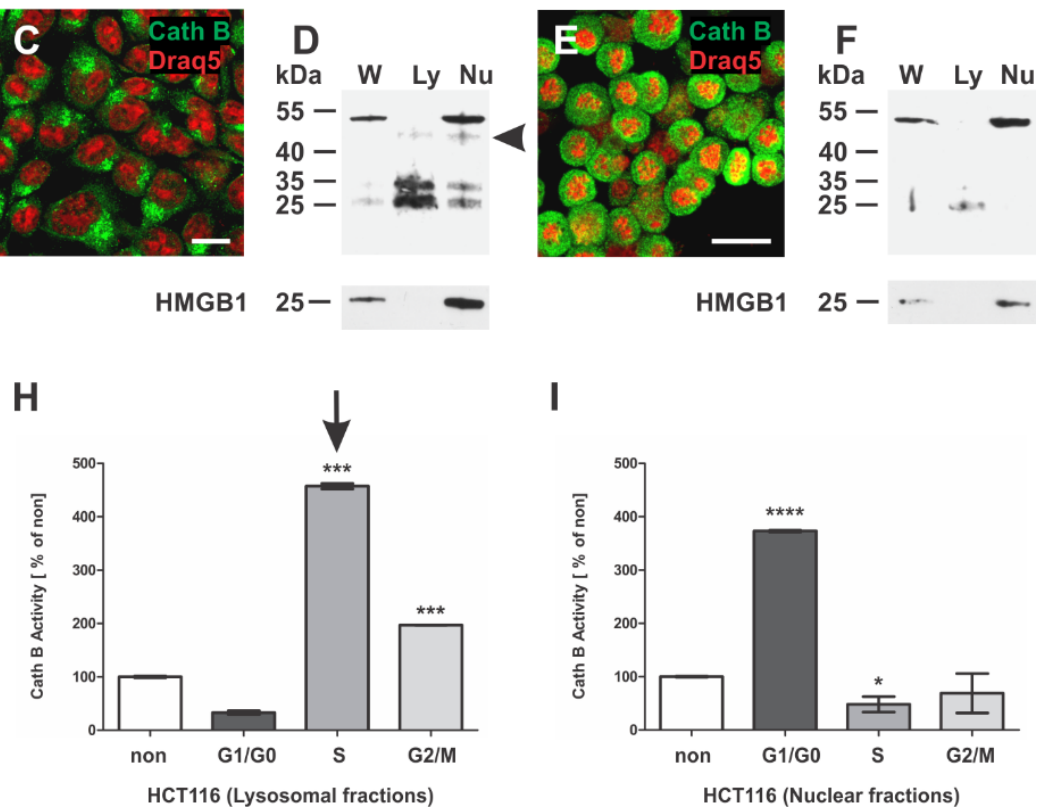

I

Figure 7. Cathepsin B expression pattern during the cell cycle of HCT116 cells. (A-F) Confocal laser scanning micrographs (A,C,E) and immunoblots of HCT116 cells and subcellular fractions prepared thereof (B,D,F, respectively), after synchronization in different cell cycle stages, i.e., G1/G0 (A,B), S (C,D), and G2/M phase (E,F). Prominent juxtanuclear localization of immunolabeled cathepsin B was observed in vesicles (green signals in A,C,E). Nuclei were counter-stained with Draq5 $5^{\mathrm{TM}}$ (red signals). In G2/M phase arrested cells, the cathepsin B-specific signal was detectable in co-localization with the Draq5 $5^{\mathrm{TM}}$-stained DNA of chromosomes in late mitotic stages (yellow signals as a result of overlapping green and red signals in E). Scale bars represent $20 \mu \mathrm{m}$. Immunoblots revealed pro- (pro), single-chain (SC), and the heavy chain of two-chain cathepsin B (HC) as indicated in whole cell lysates (W), lysosomal (Ly), and nuclear (Nu) fractions of HCT116 cells synchronized in different cell cycle stages (B,D,E). The arrowhead denotes the 40-kDa specific cathepsin B form detected within nuclear and lysosomal fractions of S-phase arrested HCT116 cells (D). (G-I) Cathepsin B activity levels were determined by cleavage of Z-Arg-Arg-AMC and are displayed in bar charts as means \pm standard deviations. Quantification was performed in comparison with non-synchronized controls (open bars) versus the indicated preparations of synchronized HCT116 cell cultures (grey bars, respectively). Levels of significance are indicated as ${ }^{*}$ for $p<0.05$, ${ }^{* *}$ for $p<0.001$, and ${ }^{* * * *}$ for $p<0.0001$.

To study whether the enzymatic activity of cathepsin B was required at all for cell cycle progression of HCT116 cells, sub-confluent cultures of HCT116 cells were serum-starved for $24 \mathrm{~h}$ for synchronization in G1/G0 phase and treated with the cathepsin B-specific inhibitor CA-074 throughout the chase period. No effect of cathepsin B inhibition was observed in such cell cultures (Figure 8A). It is important to note that neither the distribution of cathepsin B-inhibited nor that of CB-EGFP-expressing HCT116 cells in the different cell cycle phases was altered to the distribution across cell cycle phases in non-treated HCT116 cell cultures (Figure 8 cf. [35]). 
A Cath B inhibited
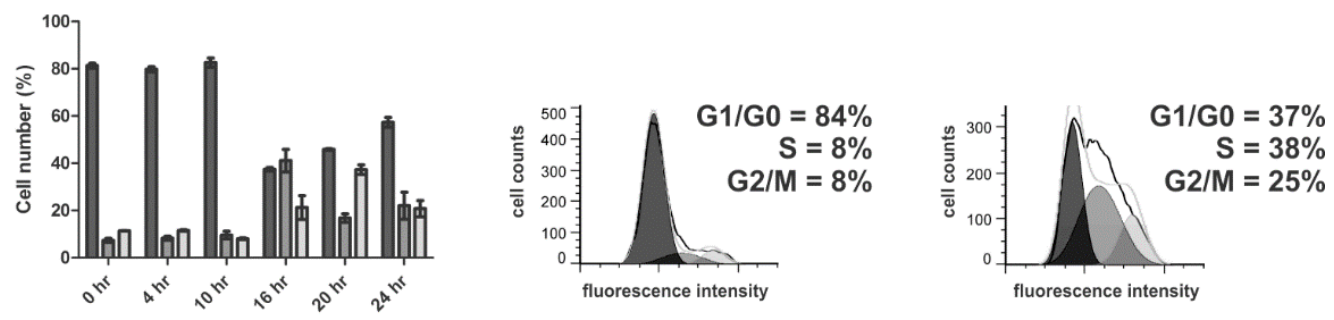

\section{B CB-EGFP}
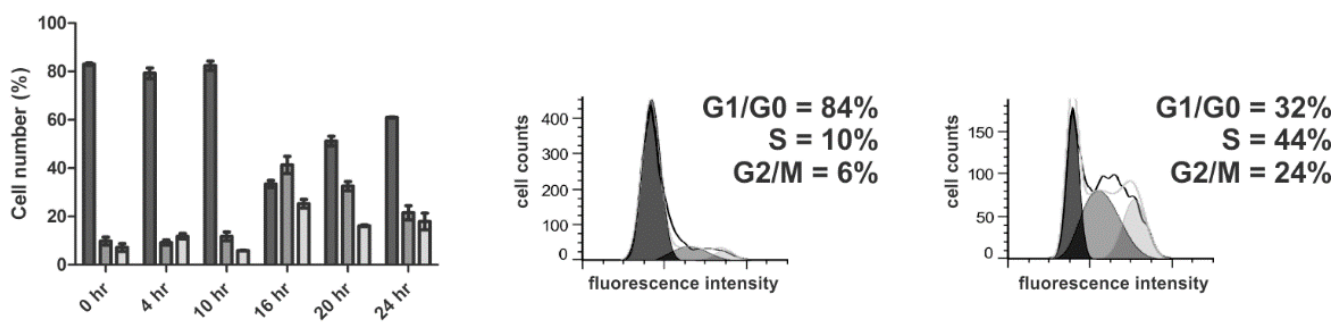

Figure 8. HCT116 cell cycle progression remains unaltered upon cathepsin B inhibition and is independent of the expression of cathepsin B-EGFP chimeras. (A,B) HCT116 cultures synchronized in G1/G0 by serum-starvation were quantified FACS analyses. Proportional distribution of cells in different cell cycle stages in cultures subjected to cathepsin B activity inhibition by CA074 treatment is depicted (A, left panel), while cultures were investigated at $24 \mathrm{~h}$ post-transfection with $p$ hCB-EGFP (B, left panel). The percentages of cells in the G1/G0, S, and G2/M phases of the cell cycle were also determined at 10 and $16 \mathrm{~h}$ release from the G1/G0 arrest (A,B, middle and right panels, respectively). Note that the typical distribution of non-treated cultures is $85 \%$ in G1/G0, $10 \%$ in S, and 5\% in G2/M at $10 \mathrm{~h}$, while $37 \%, 32 \%$, and $31 \%$ were in the respective phases at $16 \mathrm{~h}$ (see [35]). Expression of full-length cathepsin B or inhibition of cathepsin B activity had no effect on HCT116 cultures progressing through the cell cycle.

\section{Discussion}

\subsection{Unusual Sub-Cellular Locations Reached by Specific Forms of Cathepsins}

Over the last several decades, various reports have suggested an increased proteolytic activity due to over-expression of cysteine cathepsins in distinct types of malignancies such as breast, thyroid, prostate, and colon carcinoma $[5,8,13,14,32,33,43]$. Additionally, the presence of these proteases was determined to be beyond the canonical endo-lysosomal compartments, considering excessive secretion of cathepsins into the extracellular space and biosynthesis of specific forms and variants that are mis-sorted to reach the nucleus, or even the mitochondrial matrix as well as leakage out of endolysosomes $[9,11,12,30,35,38,44-48]$. For instance, cathepsin B secretion at the basal plasma membrane domain and nuclear localization of an N-terminally truncated cathepsin B variant was observed in thyroid carcinoma $[9,21,49]$.

Various transcripts of cathepsin B can be derived from the Ctsb gene due to exon skipping, by usage of alternative transcription initiation sites or by alternative splicing of pre-messenger RNAs [12]. Both full-length and exon 2-lacking transcripts can encode the same protein because the canonical start codon is present in exon 3. Alternatively, transcripts lacking exons 2 and 3 can be translated by using an alternative start codon present in exon 4 . However, transcripts lacking exons 2 and 3 encode an $\mathrm{N}$-terminally truncated form of cathepsin B. Such transcripts code for a protein that is lacking the signal peptide and the first 34 amino acid of the propeptide, thereby resulting in the biosynthesis of a cathepsin B-specific form translated in the cytoplasm [4,21,25]. Absence of the propeptide, and with this its inhibitory and chaperoning capability, may affect the folding and subsequent activation of such a cathepsin form [12,45,50,51]. There are, however, clear indications from our group's studies that N-terminally truncated cathepsin 
B forms with a molecular mass of $40 \mathrm{kDa}$ may fold properly and eventually even gain proteolytic activity, at least in thyroid carcinoma cells [9].

In the present study, we show differential localization and elevated levels of cathepsin $B$ in adenocarcinoma cells of TMA when compared to the cells in adjacent normal tissue (Figure 1). Similarly, the CRC cell line HCT116 exhibited an enhanced and, in particular, nuclear localization of cathepsin $B$ in comparison with the normal intestine epithelial cell line IEC6 (Figure 2). HCT116 cells expressed a distinct molecular form of cathepsin B characterized by a molecular mass of $40 \mathrm{kDa}$ (Figure 3) that would be consistent with an $\mathrm{N}$-terminally truncated form of cathepsin $\mathrm{B}$ that lacks the signal peptide, hence rendering the nascent chain ER-entry incompetent. As a result, the 40-kDa variant of cathepsin B would be translated in the cytoplasm and could be targeted to the nucleus of CRC cells due to productive folding.

This cathepsin B form was approached in the present study as an EGFP-tagged chimera, such that trafficking of 52NCB-EGFP was analyzed, resembling the cathep$\sin \mathrm{B}$ form derived from mutants lacking exons 2 and 3 . The $\mathrm{N}$-terminally truncated and full-length human cathepsin B were both fused to EGFP as a visualization tag and the constructed vectors (Figure 4) were transiently expressed in the human colorectal carcinoma HCT116 cell line. To confirm biosynthesis and to investigate their trafficking pathways, compartment-specific markers were used such that co-localization of the compartment-specific markers, detected through indirect immunofluorescence with the green fluorescence of the chimeric proteins, was analyzed (Figure 5). In HCT116 cells, CB-EGFP chimeras did not show any alterations from endogenous cathepsin B with respect to sorting and transport, which led us to conclude that the chimeric protein followed the expected trafficking pathway from the rER to endo-lysosomes via the Golgi apparatus and the TGN $[19,52]$. However, the subcellular localization and distribution patterns observed in this study for the N-terminally truncated human cathepsin B-EGFP, i.e., 52NCB-EGFP, did not demonstrate any prominent co-localization with compartment-specific antibodies in HCT116 CRC cells. Instead, the chimeric 52NCB-EGFP protein showed a pronounced accumulation in foci gathering in the juxtra-nuclear region, which were confirmed as representing aggresome-like inclusions by using a red fluorescent molecular rotor dye [42]. This was further confirmed by the formation of similar structures induced by treatment of HCT116 cells with the proteasome inhibitor MG-132 which induces accumulation of newly synthesized but mis-folded proteins. As expected, no aggresome formation was observed in non-transfected cells or when cells were transiently expressing EGFP only, indicating that protein homeostasis per se was not affected in HCT116 cells.

The cDNA used in this study for construction of full-length cathepsin B was derived from the human $\mathrm{HaCaT}$ keratinocyte line, while $\mathrm{N}$-terminally truncated cathepsin $\mathrm{B}$ forms were constructed with cDNA isolated from the HCT116 cell line. However, the identical cell line did not manage to properly fold the N-terminally truncated cathepsin B form, possibly due to the absence of the propeptide as a co-chaperone (see above). This highlights that the structural integrity of the propeptide can be crucial for correct folding, sorting, and transporting of cysteine cathepsins in specific cell types. Similar observations have been reported for an $\mathrm{N}$-terminally truncated form of human cathepsin $\mathrm{F}$, which has also been demonstrated to become mis-folded and to accumulate in aggresomes [53].

Aggresome formation is known as a general cellular mechanism that is initiated when the proteasome capacity is exceeded by the over-production of aggregation-prone misfolded proteins $[41,54,55]$, such that mis-folded proteins can be cleared from the cytosol by subsequent formation of autophagosomes [56]. However, reports also indicated that, in mammalian cells, aggresomes are not always part of a universal cellular response to protein misfolding [57,58].

\subsection{Cell Cycle Regulation of CRC Cells Is Independent of Cathepsin B}

Cell cycle analysis of synchronized HCT116 cultures showed that procathepsin B was predominantly present in the nucleus throughout all phases of the cell cycle, whereas a 
40-kDa form was mainly detectable in the nuclear fraction of cells arrested in the $S$ phase. Moreover, cathepsin B activity was detected in the nuclear fractions of G1/G0 arrested HCT116 cells, which can be explained by the presence of mature cathepsin B forms therein (Figure 7B,I). However, neither cathepsin B overexpression nor cathepsin B inhibition had an effect on cell cycle progression (Figure 8), indicating that cathepsin B is not involved in regulating proliferation of HCT116 cells from within the nucleus or by its endo-lysosomal functions.

Cathepsin B inhibition by the cell impermeant CA074 was recently shown to decrease the invasion capability of different CRC cell lines (HT29, DLD1, and SW480) in a Matrigelcoated trans-well assay in vitro [59], supporting the notion that it is the extracellular activity of secreted cathepsin B that is critical for promotion of a cancerous and, in particular, invasive phenotype $[4,8,12,59-61]$. In line with this notion is the observation that leakage of cathepsin B out of endo-lysosomes into the cytosol for subsequent association with chromatin of non-cancerous cells may even be important for chromosome segregation and genomic integrity [48]. In this context, it is important to note that the anti-cathepsin B signals overlapped with the Draq5 ${ }^{\mathrm{TM}}$-stained DNA of chromosomes in G2/M phase arrested HCT116 cells (Figure 7E). Thus, this observation is reminiscent of and supportive of the recent elegant work of others, determining an important role for cathepsin B in histone H3 cleavage to enable segregation of chromosomes in late mitotic stages in a pathway that is not connected to pathology, but rather important for regular mitotic cell division [15,48]. Hence, our finding that overexpression of N-terminally truncated cathepsin B, which is sorted into aggresomes, does not interfere with cell cycle progression (Figure 8) not only supports this notion but shows that a better understanding on the spatiotemporal regulation of cathepsin B-mediated proteolysis must be studied in more detail in future by considering physiological and non-physiological conditions alike [12,15,45].

\section{Conclusions and Perspectives}

In the future, it must be considered that under cathepsin B inhibition or CB-EGFP over-expression conditions, HCT116 cells could alter the expression of related cysteine cathepsins, which may act in compensation for, or in combination with, lacking or overrepresented cathepsin B, respectively, thereby changing the protein homeostasis of HCT116 cells in general. This proposal is supported by our previous findings in situ describing variable proteolytic capacities in different segments of the gastro-intestinal tract, with highest cathepsin activities in such tissue segments in which the cells deal most excessively with protein and peptide processing [40]. However, that previous study approached cathepsin redundancy in the gastro-intestinal tract in situ and thus in physiological conditions. Hence, to test the proposal of altered proteostasis underlying tumor progression in CRC, such as in HCT116 cells, comprehensive proteomics and degradomics approaches are required to clarify how precisely the expression of proteases, protease inhibitors, and protease substrates differs between normal, adenocarcinoma, or invasive and malignant CRC conditions.

Author Contributions: Conceptualization, T.T., G.M.M., M.H.H., C.J.S. and K.B.; data curation, T.T., R.W.N. and M.H.H.; formal analysis, T.T., R.W.N., R.E.B., H.B. and M.H.H.; funding acquisition, G.M.M., M.H.H., C.J.S. and K.B.; investigation, T.T., R.W.N., R.E.B., H.B. and M.H.H.; methodology, T.T., R.W.N., R.E.B., H.B. and M.H.H.; project administration, G.M.M., C.J.S. and K.B.; Resources, H.B. and C.J.S.; supervision, G.M.M., C.J.S. and K.B.; validation, T.T. and M.H.H.; visualization, T.T., R.W.N. and M.H.H.; writing—original draft, T.T., M.H.H. and K.B.; writing-review \& editing, T.T., R.W.N., R.E.B., H.B., G.M.M., M.H.H., C.J.S. and K.B. All authors have read and agreed to the published version of the manuscript.

Funding: This research was funded by DFG (Deutsche Forschungsgemeinschaft), BR 1308/10-1 and by Jacobs University Bremen, projects $2140 / 90140$ and $6113 / 90140$, to K.Br., as well as by the Norwegian South-Eastern Regional Health Authorities, project 2019081, to M.H.H.

Institutional Review Board Statement: Not applicable. 
Informed Consent Statement: Not applicable.

Data Availability Statement: All data are included in the manuscript. Note that the data of this manuscript are partially included in chapters 4.2 and 4.3 of the dissertation of T.T. that is publicly available at http:/ / nbn-resolving.org/ urn:nbn:de:gbv:579-opus-1004828 (accessed on 13 December 2021).

Acknowledgments: The authors are grateful to Maren Rehders (Jacobs University Bremen) for her excellent technical assistance.

Conflicts of Interest: The authors declare no conflict of interest. The funders had no role in the design of the study; in the collection, analyses, or interpretation of data; in the writing of the manuscript; or in the decision to publish the results.

\section{References}

1. Riese, R.J.; Chapman, H.A. Cathepsins and compartmentalization in antigen presentation. Curr. Opin. Immunol. 2000, 12, 107-113. [CrossRef]

2. Turk, V.; Turk, B.; Turk, D. Lysosomal cysteine proteases: Facts and opportunities. EMBO J. 2001, 20, 4629-4633. [CrossRef]

3. Büth, H.; Buttigieg, P.L.; Ostafe, R.; Rehders, M.; Dannenmann, S.R.; Schaschke, N.; Stark, H.J.; Boukamp, P.; Brix, K. Cathepsin $\mathrm{B}$ is essential for regeneration of scratch-wounded normal human epidermal keratinocytes. Eur. J. Cell Biol. 2007, 86, 747-761. [CrossRef]

4. Brix, K.; Dunkhorst, A.; Mayer, K.; Jordans, S. Cysteine cathepsins: Cellular roadmap to different functions. Biochimie 2008, 90, 194-207. [CrossRef]

5. Yadati, T.; Houben, T.; Bitorina, A.; Shiri-Sverdlov, R. The Ins and Outs of Cathepsins: Physiological Function and Role in Disease Management. Cells 2020, 9, 1679. [CrossRef] [PubMed]

6. Berdowska, I. Cysteine proteases as disease markers. Clin. Chim. Acta 2004, 342, 41-69. [CrossRef] [PubMed]

7. Bühling, F.; Peitz, U.; Krüger, S.; Küster, D.; Vieth, M.; Gebert, I.; Roessner, A.; Weber, E.; Malfertheiner, P.; Wex, T. Cathepsins K, L, B, X and W are differentially expressed in normal and chronically inflamed gastric mucosa. Biol. Chem. 2004, 385, 439-445. [CrossRef]

8. Mohamed, M.M.; Sloane, B.F. Cysteine cathepsins: Multifunctional enzymes in cancer. Nat. Rev. Cancer 2006, 6, 764-775. [CrossRef] [PubMed]

9. Tedelind, S.; Poliakova, K.; Valeta, A.; Hunegnaw, R.; Yemanaberhan, E.L.; Heldin, N.E.; Kurebayashi, J.; Weber, E.; Kopitar-Jerala, N.; Turk, B.; et al. Nuclear cysteine cathepsin variants in thyroid carcinoma cells. Biol. Chem. 2010, 391, 923-935. [CrossRef] [PubMed]

10. Gopinathan, A.; DeNicola, G.M.; Frese, K.K.; Cook, N.; Karreth, F.A.; Mayerle, J.; Lerch, M.M.; Reinheckel, T.; Tuveson, D.A. Cathepsin B promotes the progression of pancreatic ductal adenocarcinoma in mice. Gut 2012, 61, 877-884. [CrossRef] [PubMed]

11. Gondi, C.S.; Rao, J.S. Cathepsin B as a cancer target. Expert Opin. Ther. Targets 2013, 17, 281-291. [CrossRef] [PubMed]

12. Brix, K.; McInnes, J.; Al-Hashimi, A.; Rehders, M.; Tamhane, T.; Haugen, M.H. Proteolysis mediated by cysteine cathepsins and legumain-recent advances and cell biological challenges. Protoplasma 2015, 252, 755-774. [CrossRef] [PubMed]

13. Rudzińska, M.; Parodi, A.; Soond, S.M.; Vinarov, A.Z.; Korolev, D.O.; Morozov, A.O.; Daglioglu, C.; Tutar, Y.; Zamyatnin, A.A. The Role of Cysteine Cathepsins in Cancer Progression and Drug Resistance. Int. J. Mol. Sci. 2019, 20, 3602. [CrossRef]

14. Soond, S.M.; Kozhevnikova, M.V.; Townsend, P.A.; Zamyatnin, A.A. Cysteine Cathepsin Protease Inhibition: An update on its Diagnostic, Prognostic and Therapeutic Potential in Cancer. Pharmaceuticals 2019, 12, 87. [CrossRef] [PubMed]

15. Hämälistö, S.; Stahl-Meyer, J.; Jäättelä, M. They Might Cut It-Lysosomes and Autophagy in Mitotic Progression. Front. Cell Dev. Biol. 2021, 9, 727538. [CrossRef]

16. Vasiljeva, O.; Sevenich, L.; Reinheckel, T. Analyzing the Role of Proteases in Breast Cancer Progression and Metastasis Using Primary Cells from Transgenic Oncomice. In Metastasis: Methods and Protocols; Stein, U.S., Ed.; Springer: New York, NY, USA, 2021; pp. 275-293.

17. Olson, O.C.; Joyce, J.A. Cysteine cathepsin proteases: Regulators of cancer progression and therapeutic response. Nat. Rev. Cancer 2015, 15, 712-729. [CrossRef] [PubMed]

18. Soond, S.M.; Kozhevnikova, M.V.; Frolova, A.S.; Savvateeva, L.V.; Plotnikov, E.Y.; Townsend, P.A.; Han, Y.P.; Zamyatnin, A.A., Jr. Lost or Forgotten: The nuclear cathepsin protein isoforms in cancer. Cancer Lett. 2019, 462, 43-50. [CrossRef]

19. Linke, M.; Herzog, V.; Brix, K. Trafficking of lysosomal cathepsin B-green fluorescent protein to the surface of thyroid epithelial cells involves the endosomal/lysosomal compartment. J. Cell Sci. 2002, 115, 4877-4889. [CrossRef] [PubMed]

20. Gong, Q.; Chan, S.J.; Bajkowski, A.S.; Steiner, D.F.; Frankfater, A. Characterization of the cathepsin B gene and multiple mRNAs in human tissues: Evidence for alternative splicing of cathepsin B pre-mRNA. DNA Cell Biol. 1993, 12, 299-309. [CrossRef] [PubMed]

21. Mehtani, S.; Gong, Q.; Panella, J.; Subbiah, S.; Peffley, D.M.; Frankfater, A. In Vivo Expression of an Alternatively Spliced Human Tumor Message That Encodes a Truncated Form of Cathepsin B: Subcellular Distribution of the Truncated Enzyme in Cos Cells. J. Biol. Chem. 1998, 273, 13236-13244. [CrossRef] 
22. Müntener, K.; Willimann, A.; Zwicky, R.; Svoboda, B.; Mach, L.; Baici, A. Folding competence of N-terminally truncated forms of human procathepsin B. J. Biol. Chem. 2005, 280, 11973-11980. [CrossRef]

23. Baici, A.; Müntener, K.; Willimann, A.; Zwicky, R. Regulation of human cathepsin B by alternative mRNA splicing: Homeostasis, fatal errors and cell death. Biol. Chem. 2006, 387, 1017-1021. [CrossRef] [PubMed]

24. Berquin, I.M.; Cao, L.; Fong, D.; Sloane, B.F. Identification of two new exons and multiple transcription start points in the 5'-untranslated region of the human cathepsin-B-encoding gene. Gene 1995, 159, 143-149. [CrossRef]

25. Müntener, K.; Zwicky, R.; Csucs, G.; Rohrer, J.; Baici, A. Exon skipping of cathepsin B: Mitochondrial targeting of a lysosomal peptidase provokes cell death. J. Biol. Chem. 2004, 279, 41012-41017. [CrossRef]

26. Bestvater, F.; Dallner, C.; Spiess, E. The C-terminal subunit of artificially truncated human cathepsin B mediates its nuclear targeting and contributes to cell viability. BMC Cell Biol. 2005, 6, 16. [CrossRef] [PubMed]

27. Hölzen, L.; Parigiani, M.A.; Reinheckel, T. Tumor cell- and microenvironment-specific roles of cysteine cathepsins in mouse models of human cancers. Biochim. Biophys. Acta-Proteins Proteom. 2020, 1868, 140423. [CrossRef] [PubMed]

28. Müntener, K.; Zwicky, R.; Csucs, G.; Baici, A. The alternative use of exons 2 and 3 in cathepsin B mRNA controls enzyme trafficking and triggers nuclear fragmentation in human cells. Histochem. Cell Biol. 2003, 119, 93-101. [CrossRef] [PubMed]

29. Waghray, A.; Keppler, D.; Sloane, B.F.; Schuger, L.; Chen, Y.Q. Analysis of a truncated form of cathepsin H in human prostate tumor cells. J. Biol. Chem. 2002, 277, 11533-11538. [CrossRef]

30. Goulet, B.; Baruch, A.; Moon, N.-S.; Poirier, M.; Sansregret, L.L.; Erickson, A.; Bogyo, M.; Nepveu, A. A Cathepsin L Isoform that is Devoid of a Signal Peptide Localizes to the Nucleus in S Phase and Processes the CDP/Cux Transcription Factor. Mol. Cell 2004, 14, 207-219. [CrossRef]

31. Burton, L.J.; Henderson, V.; Liburd, L.; Odero-Marah, V.A. Snail transcription factor NLS and importin $\beta 1$ regulate the subcellular localization of Cathepsin L and Cux1. Biochem. Biophys. Res. Comm. 2017, 491, 59-64. [CrossRef]

32. Al-Hashimi, A.; Venugopalan, V.; Sereesongsaeng, N.; Tedelind, S.; Pinzaru, A.M.; Hein, Z.; Springer, S.; Weber, E.; Führer, D.; Scott, C.J.; et al. Significance of nuclear cathepsin V in normal thyroid epithelial and carcinoma cells. Biochim. Biophys. Acta Mol. Cell Res. 2020, 1867, 118846. [CrossRef] [PubMed]

33. Sloane, B.F.; List, K.; Fingleton, B.; Matrisian, L. Proteases in cancer: Significance for invasion and metastasis. In Proteases: Structure and Function; Brix, K., Stöcker, W., Eds.; Springer: Wien, Austria, 2013; pp. 491-550. [CrossRef]

34. Zhang, Z.; Yue, P.; Lu, T.; Wang, Y.; Wei, Y.; Wei, X. Role of lysosomes in physiological activities, diseases, and therapy. J. Hematol. Oncol. 2021, 14, 79. [CrossRef]

35. Tamhane, T.; Lllukkumbura, R.; Lu, S.; Maelandsmo, G.M.; Haugen, M.H.; Brix, K. Nuclear cathepsin L activity is required for cell cycle progression of colorectal carcinoma cells. Biochimie 2016, 122, 208-218. [CrossRef]

36. Büth, H. Contribution of the Lysosomal Cysteine Protease Cathepsin B to Extracellular Matrix Remodeling during Keratinocyte Migration and Wound Healing. Ph.D. Thesis, International University Bremen, Bremen, Germany, 2006.

37. Kamentsky, L.; Jones, T.R.; Fraser, A.; Bray, M.A.; Logan, D.J.; Madden, K.L.; Ljosa, V.; Rueden, C.; Eliceiri, K.W.; Carpenter, A.E. Improved structure, function and compatibility for CellProfiler: Modular high-throughput image analysis software. Bioinformatics 2011, 27, 1179-1180. [CrossRef] [PubMed]

38. Haugen, M.H.; Johansen, H.T.; Pettersen, S.J.; Solberg, R.; Brix, K.; Flatmark, K.; Maelandsmo, G.M. Nuclear legumain activity in colorectal cancer. PLoS ONE 2013, 8, e52980. [CrossRef]

39. Brix, K.; Lemansky, P.; Herzog, V. Evidence for extracellularly acting cathepsins mediating thyroid hormone liberation in thyroid epithelial cells. Endocrinology 1996, 137, 1963-1974. [CrossRef]

40. Tamhane, T.; Arampatzidou, M.; Gerganova, V.; Tacke, M.; Illukkumbura, R.; Dauth, S.; Schaschke, N.; Peters, C.; Reinheckel, T.; Brix, K. The activity and localization patterns of cathepsins B and $\mathrm{X}$ in cells of the mouse gastrointestinal tract differ along its length. Biol. Chem. 2014, 395, 1201-1219. [CrossRef] [PubMed]

41. Kopito, R.R. Aggresomes, inclusion bodies and protein aggregation. Trends Cell Biol. 2000, 10, 524-530. [CrossRef]

42. Shen, D.; Coleman, J.; Chan, E.; Nicholson, T.P.; Dai, L.; Sheppard, P.W.; Patton, W.F. Novel cell- and tissue-based assays for detecting misfolded and aggregated protein accumulation within aggresomes and inclusion bodies. Cell Biochem. Biophys. 2011, 60, 173-185. [CrossRef]

43. Jakoš, T.; Pišlar, A.; Jewett, A.; Kos, J. Cysteine Cathepsins in Tumor-Associated Immune Cells. Front. Immunol. 2019, 10, 2037. [CrossRef]

44. Reiser, J.; Adair, B.; Reinheckel, T. Specialized roles for cysteine cathepsins in health and disease. J. Clin. Investig. 2010, 120, 3421-3431. [CrossRef]

45. Brix, K.; Scott, C.J.; Heck, M.M.S. Compartmentalization of Proteolysis. In Proteases: Structure and Function; Brix, K., Stöcker, W., Eds.; Springer: Wien, Austria, 2013; pp. 85-125. [CrossRef]

46. Tholen, M.; Hillebrand, L.E.; Tholen, S.; Sedelmeier, O.; Arnold, S.J.; Reinheckel, T. Out-of-frame start codons prevent translation of truncated nucleo-cytosolic cathepsin L in vivo. Nat. Commun. 2014, 5, 4931. [CrossRef]

47. Haugen, M.H.; Boye, K.; Nesland, J.M.; Pettersen, S.J.; Egeland, E.V.; Tamhane, T.; Brix, K.; Maelandsmo, G.M.; Flatmark, K. High expression of the cysteine proteinase legumain in colorectal cancer-Implications for therapeutic targeting. Eur. J. Cancer 2015, 51, 9-17. [CrossRef] 
48. Hämälistö, S.; Stahl, J.L.; Favaro, E.; Yang, Q.; Liu, B.; Christoffersen, L.; Loos, B.; Guasch Boldú, C.; Joyce, J.A.; Reinheckel, T.; et al. Spatially and temporally defined lysosomal leakage facilitates mitotic chromosome segregation. Nat. Commun. 2020, 11, 229. [CrossRef] [PubMed]

49. Shuja, S.; Cai, J.; Iacobuzio-Donahue, C.; Zacks, J.; Beazley, R.M.; Kasznica, J.M.; O’Hara, C.J.; Heimann, R.; Murnane, M.J. Cathepsin B activity and protein levels in thyroid carcinoma, Graves' disease, and multinodular goiters. Thyroid 1999, 9, 569-577. [CrossRef] [PubMed]

50. Wiederanders, B.; Kaulmann, G.; Schilling, K. Functions of propeptide parts in cysteine proteases. Curr. Protein Pept. Sci. 2003, 4, 309-326. [CrossRef]

51. Burden, R.E.; Snoddy, P.; Jefferies, C.A.; Walker, B.; Scott, C.J. Inhibition of cathepsin L-like proteases by cathepsin V propeptide. Biol. Chem. 2007, 388, 541-545. [CrossRef] [PubMed]

52. Erickson, A.H.; Isidoro, C.; Mach, L.; Mort, J.S. Cathepsins: Getting in Shape for Lysosomal Proteolysis. In Proteases: Structure and Function; Brix, K., Stöcker, W., Eds.; Springer: Wien, Austria, 2013; pp. 127-173. [CrossRef]

53. Jerič, B.; Dolenc, I.; Mihelič, M.; Klarić, M.; Zavašnik-Bergant, T.; Gunčar, G.; Turk, B.; Turk, V.; Stoka, V. N-terminally truncated forms of human cathepsin F accumulate in aggresome-like inclusions. Biochim. Biophys. Acta (BBA)-Mol. Cell Res. 2013, 1833, 2254-2266. [CrossRef] [PubMed]

54. Johnston, J.A.; Ward, C.L.; Kopito, R.R. Aggresomes: A cellular response to misfolded proteins. J. Cell Biol. 1998, 143, 1883-1898. [CrossRef]

55. García-Mata, R.; Bebök, Z.; Sorscher, E.J.; Sztul, E.S. Characterization and Dynamics of Aggresome Formation by a Cytosolic Gfp-Chimera. J. Cell Biol. 1999, 146, 1239-1254. [CrossRef] [PubMed]

56. Williams, A.; Jahreiss, L.; Sarkar, S.; Saiki, S.; Menzies, F.M.; Ravikumar, B.; Rubinsztein, D.C. Aggregate-Prone Proteins are Cleared from the Cytosol by Autophagy: Therapeutic Implications. In Current Topics in Developmental Biology; Academic Press: Cambridge, MA, USA, 2006; Volume 76, pp. 89-101.

57. Beaudoin, S.; Goggin, K.; Bissonnette, C.; Grenier, C.; Roucou, X. Aggresomes do not represent a general cellular response to protein misfolding in mammalian cells. BMC Cell Biol. 2008, 9, 59. [CrossRef] [PubMed]

58. Wong, E.S.P.; Tan, J.M.M.; Soong, W.-E.; Hussein, K.; Nukina, N.; Dawson, V.L.; Dawson, T.M.; Cuervo, A.M.; Lim, K.-L. Autophagy-mediated clearance of aggresomes is not a universal phenomenon. Hum. Mol. Genet. 2008, 17, 2570-2582. [CrossRef] [PubMed]

59. Bian, B.; Mongrain, S.; Cagnol, S.; Langlois, M.J.; Boulanger, J.; Bernatchez, G.; Carrier, J.C.; Boudreau, F.; Rivard, N. Cathepsin B promotes colorectal tumorigenesis, cell invasion, and metastasis. Mol. Carcinog. 2016, 55, 671-687. [CrossRef] [PubMed]

60. Tedelind, S.; Jordans, S.; Resemann, H.; Blum, G.; Bogyo, M.; Führer, D.; Brix, K. Cathepsin B trafficking in thyroid carcinoma cells. Thyroid Res. 2011, 4 (Suppl. S1), 1-16. [CrossRef]

61. Sevenich, L.; Bowman, R.L.; Mason, S.D.; Quail, D.F.; Rapaport, F.; Elie, B.T.; Brogi, E.; Brastianos, P.K.; Hahn, W.C.; Holsinger, L.J.; et al. Analysis of tumour- and stroma-supplied proteolytic networks reveals a brain-metastasis-promoting role for cathepsin S. Nat. Cell Biol. 2014, 16, 876-888. [CrossRef] 